\section{Federal Leadership in High Performance Sustainable Buildings}

The Federal Government is the nation's single largest landlord and energy consumer operating more than 500,000 facilities comprising more than 3 billion square feet. Federal construction spending is approximately $\$ 30$ billion per year. Energy costs alone equal approximately $\$ 7$ billion each year.

The U.S. Department of Energy (DOE) Federal Energy Management Program (FEMP) facilitates the Federal Government's implementation of sound, cost-effective energy management and investment practices to enhance the nation's energy security and environmental stewardship. The program helps Federal agencies incorporate high performance sustainable design practices into Federal new construction, major renovations, and existing buildings. Building and operating Federal facilities in a sustainable manner has numerous benefits, including:

- Optimized life-cycle cost-effectiveness, saving taxpayer dollars.

- Safe and healthy workplaces for Federal employees through enhanced indoor environmental quality.

- Reduced environmental impact through reduced energy, water, and materials use.

- Demonstrable demand for such facilities, which helps move the overall market toward higher performance buildings.

\section{Federal Requirements for Sustainable Buildings}

Executive Order (E.O.) 13514, Federal Leadership in Environmental, Energy, and Economic Performance, represents a transformative shift in making Federal operations more

\section{Guiding Principles for Federal Leadership in High Performance and Sustainable Buildings}

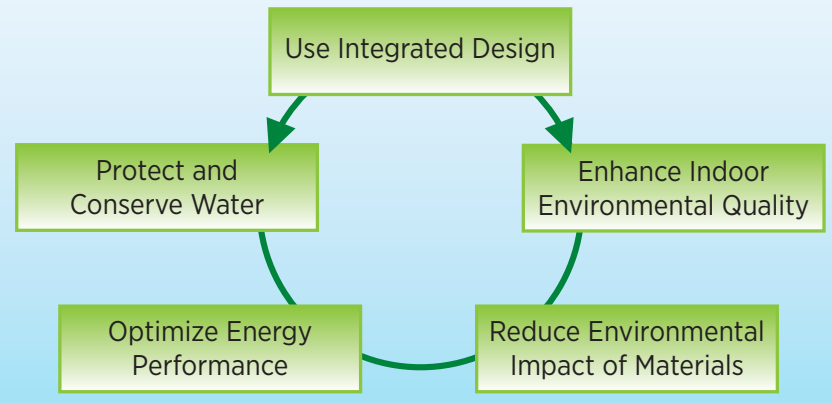

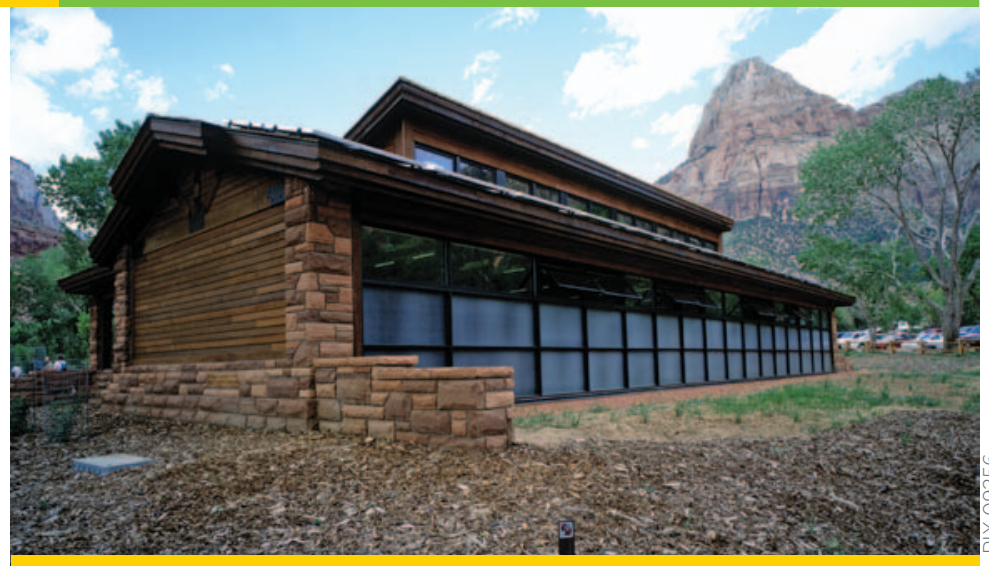

The Visitor Center at Zion National Park is a sustainable building that incorporates natural features and energy-efficient building concepts into an attractive design that saves energy and operating expenses while protecting the environment.

sustainable. Many of the E.O. 13514 goals focus on high performance and sustainable buildings, including:

- Ensure all new construction, major renovation, or repair and alteration complies with the Guiding Principles for Federal Leadership in High Performance and Sustainable Buildings.

- Ensure 15 percent of existing facilities and building leases (above 5,000 gross square feet) meet the Guiding Principles by fiscal year (FY) 2015.

- Make annual progress towards 100 percent conformance with the Guiding Principles.

- Require all Federal buildings entering the design stage in 2020 or later be designed to achieve zero net energy by 2030.

E.O. 13514 also includes many other Federal sustainability requirements related to greenhouse gas reduction, sustainable communities, water efficiency, electronic stewardship, transportation management, and pollution prevention and waste reduction. The summary of these requirements can be found at: www.femp.energy.gov/regulations/eo13514.htm/.

Both the Energy Independence and Security Act (EISA) of 2007 and the Energy Policy Act (EPAct) of 2005 have further requirements related to sustainable design and energy efficiency. Information on all key requirements, including a crosswalk of sustainability and energy goals between relevant executive orders and legislation, is available at: www.femp. energy.gov/regulations/regulations.html.

\section{Commissioning, Operations, and Maintenance}

Federal agencies must take advantage of every opportunity to make smart energy choices. Ensuring that new construction 
projects comply with sustainable design requirements is a clear approach. However, additional opportunities almost always exist for the sustainable renovation and retrofitting of current buildings. Commissioning existing facilities to optimize operations and maintenance can signifantly reduce energy intensity and help meet Federal sustainabiligy requirements and goals.

Additional information is available at: www.femp.energy.gov/ program/operations_maintenance.htm/.

\section{FEMP Assistance}

FEMP assists Federal agencies in sustainability planning and high performance building design. The program offers technical assistance in life-cycle cost analysis, energy modeling, and whole building cost and performance measurement. In addition, the Federal High Performance Sustainable Buildings Checklist is now available through the U.S. Environmental Protection Agency's (EPA) online ENERGY STAR ${ }^{\circledR}$ Portfolio Manager, an interactive tool that allows users to track and assess energy and water consumption across entire building portfolios. FEMP is available to assist agencies that are assessing their existing building stock against the Guiding Principles for Sustainable Existing Buildings by using this checklist.

FEMP also chairs the Interagency Sustainability Working Group (ISWG), which serves as an information exchange, eliminates barriers to sustainability, and provides technical guidance. The ISWG consists of approximately 300 members from across the Federal Government and private industry. ISWG priorities going forward fall into the following categories:

1. Make sustainability the standard practice.

2. Transform the existing built environment by integrating sustainability into campus and portfolio management.

3. Measure and verify building performance.

4. Institutionalize greenhouse gas management and abatement.

There has been significant progress in Federal sustainability since the start of the ISWG. One measure of that progress is the number of buildings certified under the U.S. Green Building Council's (USGBC) Leadership in Energy and Environmental Design $\left(\mathrm{LEED}^{\mathrm{TM}}\right)$ rating system. As of the end of 2009, 189 nonresidential Federal buildings achieved LEED certification, totaling more than 24 million square feet
LEED Certified Federal Buildings by Certification Level Data Through Calendar Year 2009

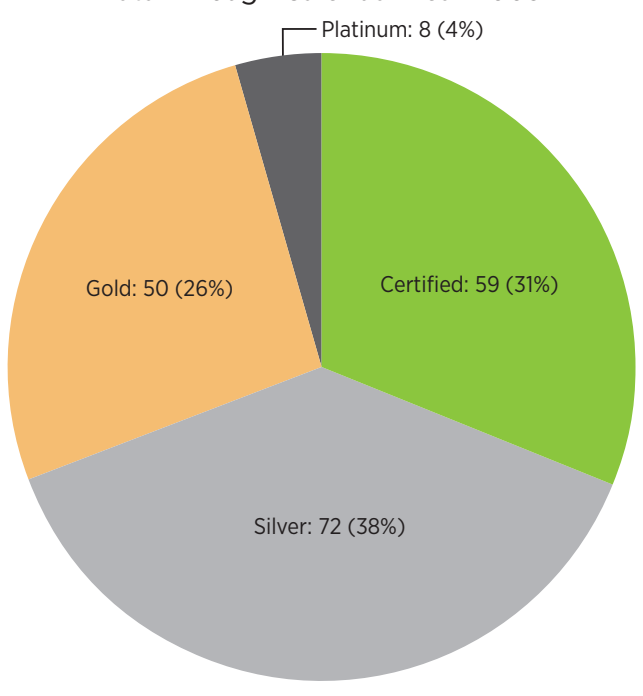

Through 2009, the Federal building portfolio contained 189 LEED certified buildings.

and located in 21 different agencies. Federal LEED certified building types vary from military barracks to national laboratories to presidential libraries. Thousands of Federal housing units are also beginning to go through the LEED certification process. In addition to LEED certification, 320 Federallyowned or leased buildings are ENERGY STAR certified, and 16 buildings have earned Green Globes certification.

Additional information is available at: www.femp.energy.gov/ program/sustainable_buildings.html

\section{Federal Resources for Sustainable Buildings}

The following provide additional resources on Federal sustainability and high performance buildings:

- FEMP High Performance Federal Buildings Database: femp.buildinggreen.com/

- Whole Building Design Guide: www.wbdg.org/

- Laboratories for the 21st Century (Labs21): www.labs21century.gov/

- FedCenter Program Areas (Green Building and Sustainability): wWw.fedcenter.gov/programs/

- ENERGY STAR for Federal Agencies: www.energystar.gov/ index.cfm?c=government.federal_agencies Renewable Energy
For additional information please contact: EERE Information Center 1-877-EERE-INF (1-877-337-3463) www.eere.energy.gov/informationcenter Printed with a renewable-source ink on paper containing at least $50 \%$ wastepaper, including $10 \%$ post consumer waste.
Prepared by the National Renewable Energy Laboratory (NREL), a national laboratory of the U.S. Department of Energy, Office of Energy Efficiency and Renewable Energy; NREL is operated by the Alliance for Sustainable Energy, LLC.

DOE/GO-102010-3034 • April 2010 